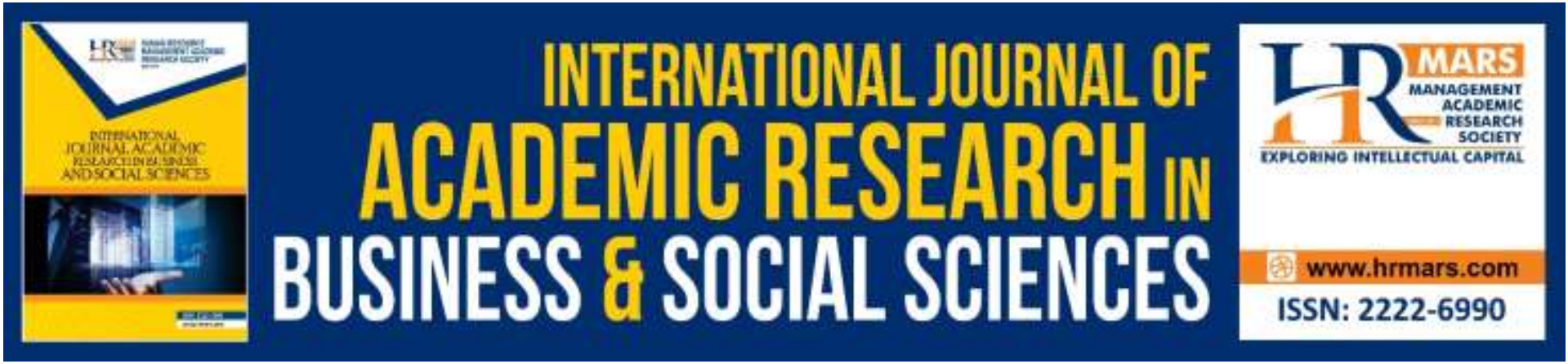

\title{
Mosques as an Agent for Community Developement in the History of Islam
}

Nizaita Omar, Zulkifly Muda, Razi Yaakob, Manapiyah Maoti

To Link this Article: http://dx.doi.org/10.6007/IJARBSS/v9-i9/6368

DOI: $10.6007 /$ IJARBSS/v9-i9/6368

Received: 12 July 2019, Revised: 10 August 2019, Accepted: 30 August 2019

Published Online: 25 September 2019

In-Text Citation: (Omar, Muda, Yaakob, \& Maoti, 2019)

To Cite this Article: Omar, N., Muda, Z., Yaakob, R., \& Maoti, M. (2019). Mosques as an Agent for Community Developement in the History of Islam. International Journal of Academic Research in Business and Social Sciences, 9(9), 763-772.

\section{Copyright: (C) 2019 The Author(s)}

Published by Human Resource Management Academic Research Society (www.hrmars.com)

This article is published under the Creative Commons Attribution (CC BY 4.0) license. Anyone may reproduce, distribute, translate and create derivative works of this article (for both commercial and non-commercial purposes), subject to full attribution to the original publication and authors. The full terms of this license may be seen at: http://creativecommons.org/licences/by/4.0/legalcode

\section{Vol. 9, No. 9, 2019, Pg. 763 - 772}

Full Terms \& Conditions of access and use can be found at http://hrmars.com/index.php/pages/detail/publication-ethics 


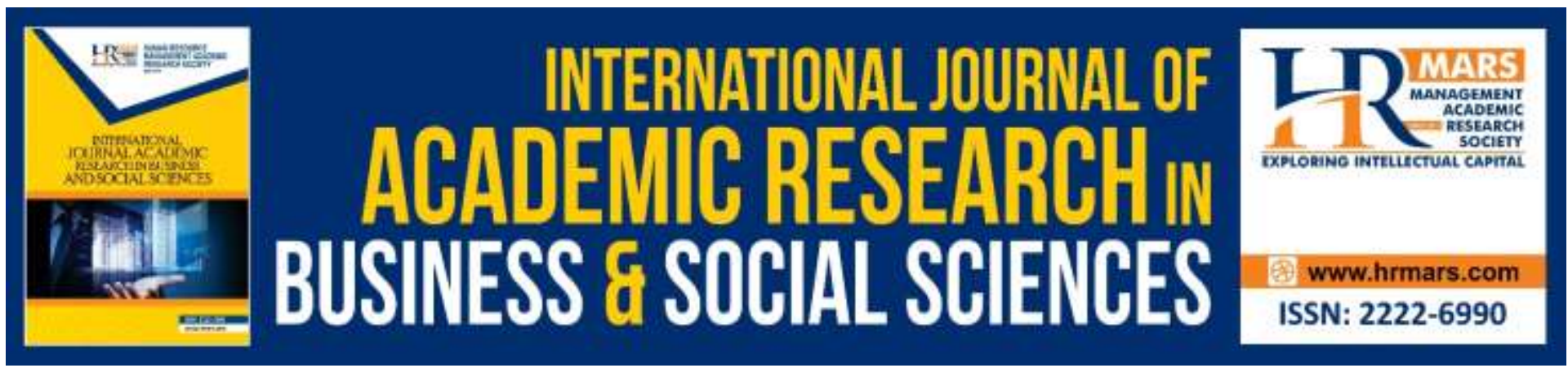

\title{
Mosques as an Agent for Community Developement in the History of Islam
}

\author{
Nizaita Omar \\ Faculty of Islamic Contemporary Studies, Universiti Sultan Zainal Abidin (UniSZA) \\ Email: nizaitaomar@unisza.edu.my \\ Zulkifly Muda \\ Fatwa Department of Terengganu, Centre of Islamic Affair, Kuala Terengganu \\ Email: zulmuda66@gmail.com
}

\section{Razi Yaakob}

Centre for Fundamental Studies, Universiti Sultan Zainal Abidin (UniSZA)

Email: raziyaakob@unisza.edu.my

\section{Manapiyah Maoti}

Academy of Islamic and Arabic Studies, Princess of Naradhiwas University

Email:maoti_pnu@yahoo.co.th

\begin{abstract}
Increasing globalization and rapid development of information technology today has changed the sociocultural patterns and living values among the global community. This phenomenon urges every party and institution involved in social agenda to devise a systematic and comprehensive preparation for any interference that might come. Accordingly, the role of mosques as an institution for social community also becomes more dynamic. The early history of Islam proves that mosques can effectively act as an agent for community transformation, inspiring this article to look into seerah nabawiyyah (the life of Prophet Muhammad) to discover the roles and functions that mosques play for the development of religion, community and nation that then results in a great civilization. Accompanying the study is a research on the position and functions of current mosques in Malaysia, which then may lead to comparison between the two and strategies on what can be done today to uplift the status of mosques. Concept paper that will be presented is derived from analyses and researches that have been done before that are improved and upgraded to be more relevant and solid. The findings suggest that mosques need to be proactively and professionally managed, and effective strategies need to be set up according to current demands.
\end{abstract}

Keywords: Social Institution, Islamic History, Phenomenon, Strategy, Development 


\section{Introduction}

Religiosity is essential to be stimulated in every individual's life, and within a society as a whole. Mobility and transformation of a community can only be acquired through a religious style of life of its inhabitants, as it acts as a strong medium for improvement and upgrading of oneself in spiritual, emotional and intellectual terms as well as it functions as the supervisor for every mindset and action established.

In this era of globalization and rapid development of information technology, every party and institution involved in social agenda needs to have a systematic and comprehensive preparation to deal with the upcoming interference(s). Efforts in bringing the society closer to the religion also need to be more integrated and effective. Plus, with current style of life that is more into material-related, religiosity will significantly help bringing the society back in track.

Mosques are a symbol of the greatness of Islam that acts as an important community institution in the development of ummah (community). The first thing that Prophet Muhammad does after relocating to Medina is building a mosque. To define a mosque, it is mostly seen as a place for human gathering to perform activities that denote their devotion and submission to Allah. Mosques also act as an institution or madrasah (school) to produce a quality human capital that is based on the tauhid (monotheism) of Islam, the manner of life proposed by al-Quran and hadiths, the Islamic morality as well as the actions and activities that project kindness. The responsibility of promoting positive values and changes in a community is on the institution of mosque.

\section{Problem Statement}

According to Ajmain (2007), the participation from the local community in programs and activities organized by the mosques has lessened. This phenomenon obscures the roles and functions of the mosques to the public. Today, the prestige of mosques is not manifest. Some of them are even disorderly and remain unfrequented most of the time especially outside prayer times (Asmak, 2007), with visitors mainly consist of people aged 40 and above (Omar, 2010). This small number of frequenters is imbalance with the big spaces and splendid facilities that these mosques offer, causing the people in charge to have quite a difficulty in coping with the management (Zaharuddin, 2007)

\section{Literature Review}

Mosques' role in cultivating and spreading the culture of knowledge acquisition is one of the common subjects reviewed and analysed by Malaysian scholars. Among of them is Momin (2003) who studies the role that mosque libraries play in expanding Islamic knowledge among local community and how mosques are considered as a medium for the spread of knowledge acquisition culture within a society. This study is particularly supported by another research done by Haron (2007) who analyzes the role of mosques as the intermediate institution in educational processes in third until fifth century. Another related study which is about the function and role of mosques as the centre of the religion of Islam and the establishment of its culture in a community is accomplished by Azmi Ahmad in 1998. The town of Seremban is selected to be researched in this study. 
The role of mosques to the people of new or young generation also catches the scholars' attention. Mustari and Azhar (2009) from Universiti Teknologi Malaysia particularly have done a research on young generation's perception on mosques today. Another research involving youth is also done by Basiron (2007) who analyzes the effectiveness of congregational programs in university mosques in producing devoted and knowledgeable students. Three universities are selected in this particular research which are Universiti Teknologi Malaysia, Universiti Kebangsaan Malaysia (National University of Malaysia) and Universiti Sains Malaysia. An akin research is also done by a group of lecturers at Universiti Utara Malaysia with the title of Memperkasakan Program Pengimarahan Masjid: Fokus kepada Pembangunan Mahasiswa IPT (Reinforcing Congregational Programs in Mosque(s): with Focus on Higher Education Students' Development) (Sabri, 2007).

\section{Objectives}

This study particularly focuses on two objectives which are:

1. To study in details the definition of mosque in Islam

2. To analyze the roles and functions of mosques as an agent for community transformation

\section{Methodology}

The methodology used in this study is mainly library research. Library research is considerably needed to obtain accurate information and clear understanding on the analysed topic. References on related books or any written sources are made to justify the concepts and theories proposed. The background of the existence and development of mosque(s) in the history of Islamic civilisation is analysed. Al-Quran and hadiths as the two primary sources of Islamic teachings are studied, along with academic reading materials such as journal articles, paperworks and books (printed and electronic) to help in scrutinizing and proposing the functions and roles of mosques for community betterment.

\section{Results}

\section{The Definition of Mosque in Islam}

The word "mosque" is mentioned 28 times in al-Quran (Abd.Al-Baqiy, 1988) while according to Muhammad al-Dawwud, al-Quran has touched on the subject of mosque 46 times after taking into consideration the related words which are saf (prayer rows), bait (house) and buyut (houses) (Abdurrahman Raden aji Haqqi, 2004). The word "mosque" itself is derived from the Arabic word masjid or masjad. Literally, it means a place for sujud (prostrating) that is taken from the verb sajada or yasjudu (IbnManzur, 2003) that technically means putting the forehead on the ground as a symbol of devotion to Allah (Al-FairuzAbadi, 1987). Customarily, "mosque" is defined as a place to perform salah (prayers) (Aziz (2007).

It is safe to say that the word "mosque" gives a basic definition of a place to perform activities that signify devotion and submission to Allah. However in Sharia terms, every place should be defined as "mosque" (al-Ubayd, 1978) as the acts of devotion and submission to Allah must be regularly executed regardless the place and time one is in. This is as stated in a hadith by Prophet Muhammad, translated as: 
From Jabir bin Abdullah, he reported that Prophet Muhammad (pbuh) said "I am given (by Allah) five things that have never been given to any prophet before me... and make for me the Earth as mosque and purity"

(Narrated by Bukhari and al Nasa'i)

Mosques are baitullah or houses of Allah as they serve as a holy and essential institution for every life aspect of human beings (Mohamed, 2004). Inside them, bondings are made between a servant and their Creator. They also function as a centre of education that works comprehensively in producing a quality human capital (Zuhdi, 2010). Mosques are mentioned as the houses of Allah in several verses of al-Quran, among them is (as translated):

The mosques of Allah are only to be maintained by those who believe in Allah and the Last Day and establish prayers and give zakah and do not fear except Allah, for it is expected that those will be of the [rightly] guided.

At-Tawbah: 18

Maintaining mosques as stated in the verse above is by performing salah in them, doing the $d u^{\prime} a$ and dhikir, and upgrading the status of Islam. Even the basic acts like mosque decoration, lamp ignition, performing ibadah (acts of worship) and zikrullah (remembrance of Allah) and knowledge sharing that are done inside the mosques are considered as the acts of 'maintaining' mosques.

However, the institution of mosque is usually only associated with ibadah and religious rituals such as salah, wirid, dhikir, du'a and celebration of Islamic festivals, while the mosque as a building is normally seen as a building for acts of worship, as the word ibadah brings the definition of a set of rituals for religious submission.

As a matter of fact, mosques should not be considered as a building and institution for ibadah only. The definition should be based on broader view of them giving advantages and benefits to the community and consequently acquiring higher status. The buildings are not for pride or display but have to function as an infrastructure that offers convenient services to the community, and upgrading the status of Islam in general as commanded by Prophet Muhammad (pbuh). Mohamad (2011) mentions a quote by Prof. Quraish Shihab in his thesis as translated below:

"If we talk about the Earth, mosques are not only places for prostrating and purifying. Here, they do not only mean as buildings for salah and even tayammum as a replacement for wudu' but also places for every human activity that denotes devotion to Allah. As so, mosques act as a port for departure as well as a harbor for arrival for Muslims"

The quote above conveys the role of mosques as a centre for social activities for Muslims. Three holy mosques in the early history of Islam which are Al-Haram Mosque, Nabawi Mosque and al-Quds Mosque have successfully proven their functions as an agent for excellent 
community transformation and mobility. There are also several mosques in Islamic countries that are not only famous as great places of worship but also as prestigious higher education institutes. Among of them are Zaitun Mosque in Tunisia, Qarawain Mosque in Morocco and Al-Azhar Mosque in Egypt. These mosques are great examplars of ideal mosques (Mohamad, 2011).

\section{The Emergence of Mosque in Islam}

In the early history of Islam, it is reported that Quba Mosque is the first mosque ever built just before the arrival of Prophet Muhammad (pbuh) and his companion Abu Bakar al Siddiq in Medina. The mosque is also the first mosque that Prophet Muhammad (pbuh) has ever performed Friday prayers in (IbnHashim, 1995), along with his other 40 companions. It is based on this event that Shafi'i madhhab (sect) presents his argument of having attended by at least 40 people as one of the conditions for the Friday prayers ceremony to be valid (Al Shawkani, n.d.).

In fact, the first thing that Prophet Muhammad (pbuh) does after arriving in Medina is finding a suitable spot to build a mosque. It is then fixed on the land owned by two brothers after being paid by Prophet Muhammad for its value. The mosque is then known as Al-Nabawi Mosque (al-Ghazali, 1976).

Mosque construction then develops rapidly afterwards. Mosques are then actively built on the lands conquered by Islam either by jihad wars or peaceful invasion. Mosques are constructed in new Islamic territories including those that are previously dominated by the kings of Rome and Parsi (Ibn Hazm, 1975). Among the earliest mosques in the history of Islam are (Haron, 2007):

(1) Haram Mosque in Mecca

(2) Nabawi Mosque in Medina

(3) Kufah Mosque in Iraq

(4) Basra Mosque in Iraq

(5) Jami' al-Mansur Mosque in Baghdad

(6) Amru bin al-As Mosque in Fustat

In the era of caliph Umar bin al-Khattab, he proposes to build small mosques for the local communities in small areas while big mosques are constructed for Friday prayers at villages that have large communities. This is similar to what we have in Malaysia. Surau (minor places of worship) are built for the convenience of the community nearby. However, for major activities like Friday prayers, they are only held at big mosques or also known as jami' mosques (Mohamad, 2011).

\section{Roles and Functions of Mosques as an Agent for Community Developement}

Conceptually, mosques play many roles and functions in every aspect of life during the era of Prophet Muhammad (pbuh). Among of them are they act as places for performing salah, having meetings or discussion, proposing opinions or complaints regarding the community and running trades and business. Plus, they also serve as the main places for foreign guests (formal and informal) to visit when they come to an Islamic country (Hawa, 1989). 
As reflected by its word, mosque or masjid (place for prostrating) mainly functions as a place for ibadah (acts of worship) such as congregational prayers, i'tikaf (meditation), al-Quran recitation, dhikir (remembrance of Allah) and tahajjud (night prayers). Adhan (prayer calls) that are done five times a day are very effective in bringing the community together to reinforce the spirit of togetherness for the sole purpose of being close to Allah.

What makes them more strategic is they also function as the centre for activity development among the local community. Muslim community back then has direct access to Muhammad's words that mostly feature the topics of religious principles, new community system and newly revealed Quranic verses (Al-Mubarkafuri, 1994), and all these access and interactions take place in mosques.

As mentioned in a hadith of Prophet Muhammad (pbuh), mosques also act as centres for the administration of a government (Abdurrahman, 2004). This is supported by historians who affirm that the activity of shura (meeting) that is regularly organized in the early Islamic era is done in mosques. In the era of Prophet Muhammad (pbuh) particularly, this shura activity is held for collective strategy planning for the battle of Uhud (al-Khudri, n.d.).

While under the governance of Umar, the shura mostly revolves around the battles of alQadisiyyah, Yarmouk and others alongside. It is narrated that Umar himself initially intends to lead the military for the battles and even gets the support from some of Muhammad's other companions, but then decides to discontinue when the shura's verdict inclines to appointing someone else, which is Sa'ad bin Abu Waqqas. All of the voting and decisionmaking processes are done in mosques (Muda, 2007).

The election of an Islamic nation's leader is basically held in mosques. An instance of this is the election of Uthman bin Affan as the national leader or caliph that is done in Nabawi Mosque. It starts with the election comittee which is led by Abdul Rahman bin Auf at that time surveying the public view on who should be the next leader (with the candidates being Uthman and Ali bin Abu Talib) in three days. Uthman then is officially appointed after gaining higher votes from the public. It is in the Nabawi Mosque that people then swear bai'ah (allegiance) to his leadership (Salim, 1982).

Most of the caliphs' inaugural speeches after the appointment are done on mosque pulpits. This is common during the eras of the Rashidun Caliphs, the Umayyad Caliphate and the Abbasid Caliphate. It is narrated that the caliph Muawiyah pronounces his intent to get the opinions and agreement from the national officials in Medina for his intention to appoint his son as his successor on the Nabawi Mosque's pulpit. Though he subsequently receives objection from some of his companions, he decides to proceed with his plan (IbnAl-Arabi, 1985).

In terms of judicial affairs, mosques work as the venues where court trials take place in. In fact, mosques are considered as the most suitable place for any court activity, according to some scholars. However, it is opposed by some other scholars who are concerned about the situations that court trials might cause that will disrupt the mosque such as voice raising. Another argument that these scholars propose is there might be a party or parties involved 
in the trials who are not allowed to be in mosques such as menstruating women (Zaidan, 1986).

The institution of mosque has been serving big and various functions in terms of education ever since its early existence. Prophet Muhammad (pbuh) builds Quba Mosque, Al-Mirbad Mosque and Nabawi Mosque in Medina to serve as centres for Islamic education (Al Tabari, 1965). Muslims learn about every area of knowledge for the concerns of the world and the hereafter in mosques. From there, intellectual and visionary scholars are produced. In the early era of Islam, mosques are particularly constitued as lecture halls, while in the era of Umar later, several corners are strictly reserved for learning activities before forming a separate building for that purpose (al-Nahlawi, 1979). Not just for the spread of religious knowledge, mosques are also treated as places for the development of various diciplines of knowledge that are within Islamic border.

The tradition of treating mosques as places of education continues until today. For example, the famous Al-Azhar University in Egypt which places its Department of $D a^{\prime}$ wah Teaching and Faculty of Usuluddin in the Al-Azhar mosque itself. There are also several other mosques in some Islamic countries that are known not for their status as mosques but as universities. Among of them are Al-Zaytuna Mosque in Tunisia, Al-Qarawiyyin Mosque in Morocco and AlAzhar Mosque (as mentioned above) in Egypt (al-Dawamy, 2007).

Also, mosques function as the centre for the development of human capital and community transformation. The mosque institution should not only be the centre of religious practices but also the centre of community welfare and social activities. Historically, mosques have been functioning as centres for receiving zakat, Zakat al-Fitr, jizyah, kharaj, ghanimah and fai'. Not only that, mosques are also considered as the centre for economic development among Muslims that involves acts of business transactions, loans and others related in them (Tajudin, 1999).

Social gatherings or meetings are also usually held in mosques, so they become places of connecting and socializing as well. Even in cases of disasters, mosques act as places which Muslims come to seek protection and express condolences to each other. Plus, for those who are poor and homeless, there is a space called suffah that is provided for them to stay, along with tents and small houses built around the mosque (Tajudin, 1999).

In a congress specifically made for the discussion on mosques held in Mecca in 1975, the roles and functions of a mosque are officially recorded. It is agreed that an effective and productive mosque fulfills the requirements below (Abdurrahman, 2004):

(1) Health-friendly prayer room(s)

(2) Specific rooms for women with specific entry(s) and exit(s) so they do not need to mingle with men. The rooms refer to both prayer room(s) and room(s) for Family Welfare Education business.

(3) Meeting room(s) and library

(4) Polyclinic and room(s) for human corpses' management

(5) Playroom(s) and sports room(s)

(6) Modesty of the building(s) 


\section{Conclusion}

The excellence and prosperity of the mosque institution become the responsibility of every Muslim. Muslims should put an effort in reinforcing the status of mosques as an effective institution and agent for community transformation and mobility in order to achieve a quality way of life communally, as the effectiveness and productivity of mosque institution depend fully on the society's support. Efforts and cooperation of all parties, from the government to the local cummunity, are essential to empower and reinforce the status of mosques in the national or even global level, and consequently restore the prestige of Islam.

To put it conclusively, mosques can be seen as a power generator that flows the electric power to every home connected with them. They are considered as the hearts for the ummah (Muslim community), of which will become null if they stop functioning.

The outcomes that will be attained in this research is hoped to invoke the society or particularly the concerned parties to bring about a model mosque as a paragon to other mosques that will be built in the future, and consequently enhance the community transformation and mobility among the society.

\section{Acknowledgement}

Highest appreciation is given to Universiti Sultan Zainal Abidin for the sponsor provided for this research through the University Research Grant Funds 2017 - R0009-360. This is the first research done since the grant started.

\section{Corresponding Author}

Nizaita Omar, Faculty of Islamic Contemporary Studies, Universiti Sultan Zainal Abidin (UniSZA), Gong Badak Campus, 21300 Kuala Nerus, Kuala Terengganu, Terengganu, Malaysia. Email: nizaitaomar@unisza.edu.my

\section{References}

Salim, A. A. (1982). Tarikh al daulah al Arabiyyah, Iskandariya: Muassasah al Syabab al Jamiah Al-Nahlawi, A. R. (1979). Usul al tarbiyyah al Islamiyyah wa Asalibuhu, Damascus: Dar al Fikr Zaidan, A. K. (1986). Nizam al Qada' fi al Islam, Beirut: Muassasah al Risalah

Mohamad, A. (2011). Kajian Penilaian Program Pemantapan Akidah di Masjid Negeri Terengganu, Doctoral Thesis of Universiti Malaysia Terengganu

Haqqi, A. R. (2004). Peranan Masjid Masakini: Satu Penilaian Berkaitan dengan Kedudukannya sebagai Wadah Kepimpinan Raja, Paperwork for the Seminar of Mosque Institution organized by the Department of Prime Minister of Brunei held on 19th to 21st of July 2004

IbnAl-Arabi, A. B. (1985). Al Awasim Min al Qawasim, Beirut: Dar al Kutub Al Syawkani (n.d.). Nayl al Awtar, Cairo: Maktabah al Kulliyyat al Azhariyyah Abadi, A. F. (1987). al-Kamus al-Muhit. Beirut: Muassasah al-Risālah Al-Tabari, (1965). Tarikh al-Umam wa al-Muluk, Cairo: Matbaah al-Hasaniyyah al-Misriyyah Al-Dawamy, A. R. (2007). Falsafah Dan Fungsi Masjid Dalam Islam, Paperwork for Seminar of Mosques' Roles organized by UTM IbnHazm. (1975). Al-Fasl fi al-Milal-wa al-Ahwa' wa al-Nihal. Beirut: Dar al-Makrifah IbnHisham. (1995). Sirah al-Nabawiyyah li Ibn Hisham, Beirut: Dar al Jil 
IbnManzur (2003) Lisan al- Arab. Cairo: Dar al Hadith

Al-Ubayd, M. R. (1978). Makanatul Masjid wa Risalatuhu

Al-Baqiy, M. F. (1988), Al Mu'jam al Mufahras li Alfaz al Quran al Karim, Cairo: Dar al Hadith

Tajudin, M. (1999). Peranan Kurikulum dalam Reka Bentuk Masjid sebagai Pusat Pembangunan Masyarakat. Skudai: Universiti Teknologi Malaysia

Al-Ghazali, M. (1976), Fiqh Seerah, Cairo: Dar al Kutub al Hadithiyyah

Al-Khudri, M. (n.d.), Nur al Yaqin, Cairo: Matba'ah al Istiqamah

Hawa, S. (1989). Al Asas fi al Sunnah wa Fiqhiha al seerah al Nabawiyyah, Cairo: Dar al Salam Haron, Z. (2007). Kajian Masjid Sebagai Institusi Pengantara dalam Proses Pendidikan: Sorotan Abad $3 \mathrm{H}$ hingga $5 \mathrm{H}$, in the book Mosques as the Medium for Human Capital Development, Skudai: Universiti Teknologi Malaysia

Muda, Z. (2007). Limitasi dan Absulotasi Aktiviti Masjid Menurut Perundangan Islam, in the book of Masjid Pemangkin Pembangunan Modal Insan, Skudai: Universiti Teknologi Malaysia 